\title{
The Regulation of Human Germline Genome Modification in Italy
}

\author{
Ludovica Poli
}

\section{INTRODUCTION}

For historical, social, political, and religious reasons, Italy has traditionally approached life sciences, especially those involving humans, with great caution. The main law touching on human germline genome modification, called Law 40/2004 "Rules on Medically Assisted Reproduction," bans most "experimentation" on human embryos but, at the same time, fails to define what an embryo is and, surprisingly, might have left the door open to clinical application of therapies that modify the human germline genome.

This chapter first discusses the general regulatory environment for scientific work involving human germline genome modification. After having introduced the hierarchy of norms in the Italian legal system, it considers in detail relevant provisions of the Italian Constitution, European Union (EU) law, international treaties ratified by Italy, and Law 40/2004. The second part of the chapter aims at assessing whether and to what extent research using human germline genome modification technologies, as well as clinical applications of such techniques, is permitted under the Italian legal system. Finally, it offers some remarks on future perspectives.

\section{THE GENERAL LEGAL SYSTEM}

In the Italian legal system, sources of law are arranged hierarchically. The Constitution of the Italian Republic (Costituzione della Repubblica Italiana) ${ }^{2}$

Law 19, No. 40 (Rules on Medically Assisted Procreation) 2004.

2 Constitution of the Italian Republic (entered into force on January 1, 1948) (Italian Constitution). 
is the apex of the system, the fundamental source of law providing the legal basis for other sources, as well as for the activities of the public authority. ${ }^{3}$

International law becomes part of the Italian legal system in different ways, depending on whether it is customary, treaty, or EU law. According to Article 10 of the Constitution, the national legal system "conforms to the generally recognized rules of international law." As confirmed by the Constitutional Court, the Constitution refers to international customary rules in general, with the exclusion of international treaties. ${ }^{4}$ International customary law prevails over both ordinary laws and the Constitution itself, with the only exception for the fundamental principles stated therein. ${ }^{5}$

Norms contained in treaties other than those of the EU legal system become part of the domestic legal system through a special incorporation procedure, by an act of Parliament. ${ }^{6}$ Although they become part of the Italian legal system by virtue of an ordinary law, they assume a rank superior to statutory law (ordinary laws and sub-legislative acts) but not the Constitution. ${ }^{7}$ Treaties that have been incorporated in the Italian legal system must conform to every article of the Constitution, not just to its core values. The Italian Constitutional Court might be called to verify the constitutional legitimacy of norms contained in treaties that have been ratified by Italy, with the aim to strike a "reasonable balance between the duties flowing from international law obligations, as imposed by Article 117.1 of the Constitution, and the safeguarding of the constitutionally protected interests contained in other articles of the Constitution." 8

As far as EU law is concerned, among the legislative acts listed under Article 288 of the Treaty on the Functioning of the European Union, regulations (as well as decisions addressing persons other than states) are directly applicable in all EU member states: they do not need any implementing legislation by national parliaments. Directives and decisions addressing states, on the contrary, require national parliaments to enact proper legislation for implementation. Be that as it may, both directives and decisions might still have direct

3 In particular, constitutional law and laws of constitutional reform; ordinary law, law decree and legislative decree; regional law; government regulations; habit or custom.

4 Constitutional Court Judgment Nos. 15/1996, 348/2007 and 349/2007.

5 Constitutional Court Judgment No. 48/1979, para. 3.

6 The so-called order of execution (ordine di esecuzione) is contained in an ordinary law requiring the implementation of the treaty.

7 These conclusions are based on the interpretation of Art. 117.1 of the Italian Constitution, providing that "[l] egislative powers shall be vested in the State and the Regions in compliance with the Constitution and with the constraints deriving from EU legislation and international obligations"; Constitutional Court Judgment Nos. 348/2007 and 349/2007.

8 Constitutional Court Judgment No. 349/2007, para. 4.7. 
effects to the extent they impose an unconditional and sufficiently clear and precise obligation on member states, for instance when they create individual rights which national courts must protect. ${ }^{9}$

Crucially, EU law has primacy over Italian law. Not only must Italian law be interpreted consistently with it, but, as confirmed by the Italian Constitutional Court, Italian judges must set aside domestic law, whenever incompatible with EU law. ${ }^{10}$ The only exception to the primacy of EU law is a subset of fundamental principles and constitutional rights, the core values of the Italian legal system, which can never be breached by EU law. ${ }^{11}$ In case of conflict between EU law and these fundamental principles, the Italian Constitutional Court will exercise its power to verify the constitutional legitimacy of the EU law and might set it aside to give precedence to the Constitution. $^{12}$

\section{REGULATORY ENVIRONMENT}

\section{Constitution of the Italian Republic, EU Law, and Treaties}

Human germline genome modification technologies, which have enormous therapeutic potential, can further certain values enjoying a constitutional status under the Italian legal system, such as the promotion of scientific progress and the protection of health. In fact, according to the Constitution, Italy "promotes the development of culture and of scientific and technical research"13 and "safeguards health as a fundamental right of the individual and as a collective interest." ${ }^{4}$ Both are to be considered core values of the Italian legal system.

The right to science and the right to health are also guaranteed under the International Covenant on Economic, Social and Cultural Rights (ICESCR), which Italy ratified in $1978 .{ }^{15}$ Article 12 provides "the right of everyone to the

9 R Adam, A Tizzano, Manuale di Diritto dell'Unione Europea (Giappichelli 2017) 173-183.

10 Constitutional Court Judgment No. 170/1984, Granital. The Court has based its conclusions on the interpretation of Art. 11 of the Italian Constitution, allowing limitations of sovereignty that may be necessary to participate in international organizations aiming at ensuring peace and justice among nations.

11 Constitutional Court Judgment Nos. 168/1991 and 115/1993.

12 This position has been confirmed by the Court of Justice of the European Union in the Judgment of December 5, 2017 (Grand Chamber), case C-42/17 M.A.S. and M.B (Taricco II), released upon the request for a preliminary ruling from the Italian Constitutional Court (Order No. 24/2017).

13 Italian Constitution, art. 9.

14 Ibid., art. 32.

15 International Covenant on Economic, Social and Cultural Rights (adopted 16 December 1966, entered into force January 3, 1976) 999 UNTS $_{3}$ (ICESCR). 
enjoyment of the highest attainable standard of physical and mental health," while Article 15 enshrines the right "to enjoy the benefits of scientific progress and its applications," as well as the "the freedom indispensable for scientific research and creative activity." The right to health is recognized in numerous international instruments and has already been the object of exhaustive elaboration (including in the General Comment No. $14,{ }^{16}$ adopted by the Committee on Economic, Social and Cultural Rights in 2000). On the contrary, the contents of the right to science are still debated and its centrality in the human rights discourse is rarely invoked. However, as stressed by the Special Rapporteur in the Field of Cultural Rights, Ms. Farida Shaheed, "scientific innovations are changing human existence in ways that were inconceivable a few decade ago." ${ }^{17}$ Science not only offers solutions to individual, social, economic, and developmental issues, but it also has an autonomous standing among other fundamental rights. The meaning of science, thus, is not just instrumental to the realization or improvement of other rights, it has also an inherent value strictly linked to the idea of dignified human life that goes beyond survival and security needs. ${ }^{18}$

While a General Comment on Article 15 of the ICESCR is being drafted, some indications on the normative content of the right come from the above-mentioned report by the Special Rapporteur, as well as from the Venice Statement on the Right to Enjoy the Benefits of Scientific Progress and Its Applications. ${ }^{19}$ In particular, the definition of the scope of the right to enjoy the benefits of scientific progress and its applications is of key relevance for the purposes of the present study. In this regard, it is useful to insist on two specific points.

First, the expression "benefits of scientific progress" makes it clear that these benefits "encompass not only scientific results and outcomes but also the scientific process, its methodologies and tools." ${ }^{20}$ In other words, even the

16 Committee on Economic, Social and Cultural Rights, "General Comment No. 14 - The Right to the Highest Attainable Standard of Health (Art. 12)" (August 11, 2000) E/C.12/2000/4.

17 HRC "Report of the Special Rapporteur in the Field of Cultural Rights, Farida Shaheed on the Right to Enjoy the Benefits of Scientific Progress and its Applications" (14 May 2012) A/ HRC/2o/26, para. 1 (Report of the Special Rapporteur in the Field of Cultural Rights).

18 L Shaver, "The Right to Science: Ensuring that Everyone Benefits from Scientific and Technological Progress" (2015) 411 Journal européen des droits de l'homme - European Journal of Human Rights 416.

19 The Venice Statement on the Right to Enjoy the Benefits of Scientific Progress and its Applications is the outcome of three expert meetings held between June 2007 and July 2009 under the auspices by UNESCO in collaboration with the Amsterdam Centre for International Law, the Irish Centre for Human Rights, and the European Inter-University Centre for Human Rights and Democratization (Venice Statement) www.aaas.org/sites/defa ult/files/VeniceStatement_Julyzoog.pdf accessed February 27, 2018.

20 Venice Statement, para. 8 . 
general enhancement of the conditions for further scientific activity is to be considered a benefit. This is a key issue as it permits to stress that basic research also, and not only applied research, is covered by the right to science.

Second, the term "enjoyment" has to be considered as covering not only the dissemination of the outcomes of the scientific progress ${ }^{21}$ but also the participation in its development. This has been confirmed by the Special Rapporteur in the Field of Cultural Rights, who stated that the normative content of the right envisaged under Article 15 of the ICESCR includes, along with the "access to the benefits of science by everyone, without discrimination," the "participation of individuals and communities in decision-making" and also "opportunities for all to contribute to the scientific enterprise and freedom indispensable for scientific research." 22

Thus, any total ban of research on human germline genome modification techniques would certainly imply a violation of Article 15 of the ICESCR, interfering with scientific progress and impairing the right of many people to enjoy the benefits of science and its applications.

However, as the debate over the human germline genome modification demonstrates, while the benefits of intervening on gametes or on early-stage embryos to treat genetic diseases are evident, there is also fear that germline modifications might leave room for abuses. ${ }^{23}$ For example, human germline genome modification techniques could be used to enhance traits with no therapeutic need. This generates "a public discomfort [...] whether for fear of exacerbating social inequities or of creating social pressure for people to use technologies they would not otherwise choose."24 Moreover, along with other genetic technologies, human germline genome modification might be considered as having an implicit and inherent eugenic nature. Eugenics, as such,

21 The access to scientific knowledge, even in the form of right to science education, is a pivotal aspect of the right to science and it is also a precondition for its full realization, as well as for the concrete possibility to make informed decisions. Report of the Special Rapporteur in the Field of Cultural Rights (n 17) para. 27; Ibid. para. 22.

22 Ibid. para. 25 .

23 J Sugarman, "Ethics and Germline Gene Editing" (2015) EMBO reports http://embor .embopress.org/content/16/8/879 accessed 27 February 2018; T Ishii, "Germline GenomeEditing Research and its Socioethical Implications" [2015] 21:8 Trends in Molecular Medicine 473; T Ishii, "Reproductive Medicine Involving Genome Editing: Clinical Uncertainties and Embryological Needs" (2017) 27 Reproductive BioMedicine Online www.rbmojournal.com/arti cle/S1472-6483(16)30549-1/fulltext accessed 27 February 2018; MH Porteus, CT Dann, "Genome Editing of the Germline: Broadening the Discussion" (2015) 23:6 Molecular Therapy 980; KS Bosley and others "CRISPR Germline Engineering - The Community Speaks" (2015) 33 Nature Biotechnology 478.

24 National Academies of Science, Engineering and Medicine, Human Genome Editing. Science, Ethics, and Governance (National Academies Press 2017) 9. 
"is concerning because it could be used to reinforce prejudice and narrow definitions of normalcy in our societies." ${ }^{25}$ It "sends a message about the 'fitness' of [certain] traits or conditions, thereby reflecting on the worth and value of people who have that trait in our society." 26

Eugenic practices, and in particular "those aiming at the selection of persons," are explicitly prohibited under Article 3.2 of the Charter of Fundamental Rights of the European Union, ${ }^{27}$ which affirms the right to the integrity of the person in the fields of medicine and biology. In the Italian legal system, the Charter has the same value as EU treaties and enjoys primacy over Italian law. According to the explanations attached to the Charter, Article 3.2 refers to "possible situations in which selection programmes are organized and implemented, involving campaigns for sterilization, forced pregnancy, compulsory ethnic marriage among others, all acts deemed to be international crimes in the Statute of the International Criminal Court adopted in Rome on 17 July 1998." ${ }^{28}$ The drafters of the EU Charter, thus, had the intention to ban projects aimed at the improvement of the human race based on the selection by the State of who can procreate. They meant to ban "traditional" applications of eugenics, one that harks back to the horrors of World War II. However, concerns about a potential new method of selection, realized through genome manipulation, are not completely illfounded. Future parents are now in a position to know in advance the genetic makeup of their children, and human germline genome modification could therefore open the door to the "production" of "designer babies," with parents making decisions about their children's genes in view of an improvement that goes beyond the treatment of medical disorders. Indeed, to some extent, these technologies allow a new form of eugenics, transforming parents from "victims" of a State's impositions to be "responsible" for choices imposed on their children. ${ }^{29}$

25 KE Ormond and others, "Human Germline Genome Editing" (2017) 101 Am J Hum Genet 167,171 .

26 Ibid. 172 .

27 Charter of the Fundamental Rights of the European Union (ratified December 7, 2000, entered into force December 1, 2007) (2000) OJ C 364/1.

28 Explanations Relating to the Charter of Fundamental Rights (2007) OJ C 303. Although they do not have the status of law, the explanations are considered a valuable tool of interpretation intended to clarify the provisions of the Charter.

29 C Campiglio, "Eugenetica e diritto internazionale" in N Boschiero (ed.), Ordine internazionale e valori etici: VIII Convegno, Verona, 26-27 giugno 2003 (Editoriale Scientifica 2004) 453, 461. See also DJ Galton, "Eugenics: Some Lessons from the Past" (2005) 10:1 Reproductive BioMedicine Online 133 www.rbmojournal.com/article/S1472-6483(10)62222-5/pdf accessed February 27, 2018; JN Missa, "From State Eugenics to Private Eugenics" (1999) 13:4 Best Practice E Research Clinical Obstetrics \& Gynaecology 533. 
However, such a controversial issue has to be contextualized. Human germline genome modification needs to be discussed in a more comprehensive framework, including all the possible techniques potentially determining a selection of individuals, and keeping in mind human rights. This is the approach followed by the European Court of Human Rights (ECtHR) in the case Costa and Pavan v. Italy..$^{30}$ In that case, the Court was called to decide on the compatibility of Italy's ban of preimplantation genetic diagnosis (PGD) with the European Convention. In its decision, the Court stressed that concerns regarding "eugenic" uses of PGD would not be sufficient to justify banning it. Selectivity is not just a distinctive element of PGD, and therefore it does not represent a sufficient reason to exclude its applicability. This position was subsequently confirmed by the Italian Constitutional Court in Judgment No. 96/2015. ${ }^{31}$

A more explicit limit to human germline genome modification comes from the Convention for the Protection of Human Rights and Dignity of the Human Being with Regard to the Application of Biology and Medicine, adopted within the Council of Europe in 1997 (also known as the Oviedo Convention)..$^{32}$ Article 13 of the Oviedo Convention entitled "interventions on the human genome" reads as follows: "An intervention seeking to modify the human genome may only be undertaken for preventive, diagnostic or therapeutic purposes and only if its aim is not to introduce any modification in the genome of any descendants." ${ }_{3}$ The provision, along with others contained in Chapter IV on the "human genome," is clearly inspired by the precautionary principle and it is strictly connected to the "slippery slope argument"

30 European Court of Human Rights Costa and Pavan v. Italy (2012) application no. 54270/ 10, para 63. For a more detailed analysis: L Poli, "La diagnosi genetica pre-impianto al vaglio della Corte Europea dei diritti dell'uomo" (2013) a Rivista di Diritto Internazionale 119; L Poli, "Pre-implantation Genetic Diagnosis under the European Court of Human Rights' Review: An Opening toward a Wider Acceptance of the Technique in Europe?" (2013) 4 CYIL 141.

31 Constitutional Court Judgment No. 96/2015, declaring the unconstitutionality of Art. 1.1, 1.2, and 4.1 of Law No. 40/2004. According to the Court, the exclusion of fertile people carriers of transmittable genetic diseases from medically assisted reproduction technology was in breach of Art. 3 of the Constitution, guaranteeing the principle of equality. The Court found that this exclusion unreasonably balanced the interests at stake and violated the criterion of reasonableness of the legal order, considering that while Law 40/2004 prohibited women from acquiring information about the embryo through preimplantation genetic diagnosis, any fetus affected by genetic disease could be legally aborted.

32 Convention for the Protection of Human Rights and Dignity of the Human Being with Regard to the Application of Biology and Medicine (adopted April 4, 1997, entered into force December 1, 1999) ETS 164 (Oviedo Convention).

33 Ibid., art. 13. 
developed in bioethics. ${ }^{34}$ As the Explanatory Report of the Oviedo Convention makes clear, the provision aims at addressing the fear that misuse of the progress of science in the field of genome editing "may endanger not only the individual but the species itself," through the "intentional modification of the human genome so as to produce individuals or entire groups endowed with particular characteristics and required qualities." ${ }^{35}$ Although from a bioethical perspective germline editing is widely perceived as a technology that might "cross a line many have viewed as ethically inviolable, ${ }^{66}$ it remains unclear to what extent an intervention seeking to impede the transmission of a serious disease would "endanger the species itself" as mentioned in the Explanatory Report. The fear of potential eugenics drifts is traceable in the provision, along with the uncertainty surrounding the balance between risk and benefits connected to the application of human germline genome modification techniques.

Be that as it may, the Oviedo Convention is not currently binding for Italy. Although the Italian Government signed it, and authorization to ratification was given by the Parliament with Law 145/2001, it was never ratified. ${ }^{37}$ Granted, Article 18 of the 1969 Vienna Convention on the Law of Treaties contains an obligation not to defeat the object and purpose of a treaty prior to its entry into force..$^{8}$ This "pre-conventional obligation" is a key principle of international law, being the expression of "good faith taken in the sense of

34 IR Pavone, La Convenzione europea sulla biomedicina (Giuffrè Editore 2009) 72-73. See also R Andorno "The Oviedo Convention: A European Legal Framework at the Intersection of Human Rights and Health Law" (2005) 2:4 JIBL 133.

35 Explanatory Report to the Convention for the Protection of Human Rights and Dignity of the Human Being with Regard to the Application of Biology and Medicine: Convention on Human Rights and Biomedicine (1997) European Treaty Series No. 164, para. 89.

$3^{6}$ National Academies of Science, Engineering and Medicine, Human Genome Editing (n 24) 7; Parliamentary Assembly of the Council of Europe Recommendation 2115: The Use of New Genetic Technologies in Human Beings (October 12, 2017) (Parliamentary Assembly of the Council of Europe, The Use of New Genetic Technologies in Human Beings).

37 Law No. 145/2001, "Ratification and implementation of the Council of Europe Convention for the Protection of Human Rights and Dignity of the Human Being with regard to the Application of Biology and Medicine: Convention on Human Rights and Biomedicine, adopted in Oviedo on 4 April 1997, as well as the Additional Protocol of 12 January 1998, n. 168, on the prohibition of cloning of human beings" (Ratifica ed esecuzione della Convenzione del Consiglio d'Europa per la protezione dei diritti dell'uomo e della dignità dell'essere umano riguardo all'applicazione della biologia e della medicina: Convenzione sui diritti dell'uomo e sulla biomedicina, fatta a Oviedo il 4 aprile 1997, nonché del Protocollo addizionale del 12 gennaio 1998, n. 168, sul divieto di clonazione di esseri umani).

$3^{8}$ Vienna Convention on the Law of Treaties (adopted May 23, 1969, entered into force January 27, 1980) 1155 UNTS 331. Art. 18 reads as follow: "A State is obliged to refrain from acts which would defeat the object and purpose of a treaty when: (a) It has signed the treaty or has exchanged instruments constituting the treaty subject to ratification, acceptance or 
protection of legitimate expectations of a minimal loyal behavior." 39 One could argue that, even in the absence of a ratification, Italy is called nonetheless to act consistently with the object and purpose of the Oviedo Convention, namely "the protection of the dignity and identity of all human beings and the guarantee for everyone, without discrimination, of the respect for integrity and other rights and fundamental freedoms with regard to the application of biology and medicine." 40 However, the indeterminacy of the notion of "human dignity," which not only is unsatisfactorily explained in the Explanatory Report ${ }^{41}$ but is also hardly definable as an objective value, taking the shape of "a right of humanity," ${ }^{2}$ does not allow us to conclude that human germline genome modification applications per se are contrary to the object and purpose of the Oviedo Convention.

In sum, while international law seems to pose concrete limitations to the development and application of human germline genome modification, a deeper analysis demonstrates that the need to avoid misuses of these techniques is not incompatible with an opportune regulation of these methods. This is also the approach recently taken by the Council of Europe. In October 2017, the Parliamentary Assembly of the Council of Europe adopted a resolution recognizing that, while the Oviedo Convention prohibits intervention on germline genome, nothing precludes a possible amendment of the treaty, to be implemented in line with the obligation contained in Article 28 of the Convention, under which States parties must ensure that "the fundamental questions raised by the developments of biology and medicine are the subject of appropriate public discussion in the light, in particular, of relevant medical, social, economic, ethical and legal implications, and that their possible

approval, until it shall have made its intention clear not to become a party to the treaty; or (b) It has expressed its consent to be bound by the treaty, pending the entry into force of the treaty and provided that such entry into force is not unduly delayed". O Dörr, "Art. 18. Obligation not to defeat the object and purpose of a treaty prior to its entry into force," in O Dörr and K Schmalenbach (eds.) Vienna Convention on the Law of Treaties: A Commentary (Springer 2018) 243 .

39 R Kolb, Good Faith in International Law (Hart Publishing 2017) 43.

40 Oviedo Convention, art. 1.1.

${ }^{41}$ The Explanatory Report does not provide a definition of "human dignity," rather it focuses on the extension of the protection, in particular stressing, at para 19, that "[t]he Convention (...) uses the expression 'human being' to state the necessity to protect the dignity and identity of all human beings. It was acknowledged that it was a generally accepted principle that human dignity and the identity of the human being had to be respected as soon as life began."

42 P De Sena, "Dignità umana in senso oggettivo e diritto internazionale" (2017) Diritti umani e diritto internazionale 573. See also C McCrudden, "Human Dignity and Judicial Interpretation of Human Rights" (2008) 19:4 EJIL 655; P Sykora, A Caplan, "Germline Gene Therapy is Compatible with Human Dignity” [2017] 18 EMBO reports 2086. 
application is made the subject of appropriate consultation." 43 Additionally, the Parliamentary Assembly, while urging "member States which have not yet ratified the Oviedo Convention to do so without further delay, or, as a minimum, to put in place a national ban on establishing a pregnancy with germline cells or human embryos having undergone intentional genome editing," has also explicitly encouraged the development of a common regulatory and legal framework to balance "potential benefits and risks of these technologies aiming to treat serious diseases, while preventing abuse or adverse effects of genetic technology on human beings." 44

An opportune regulation would be therefore in line with international sources calling for caution toward possible misuses of the techniques and would represent at the same time a full realization of the right to science as provided for both in the ICESCR and in the Italian Constitution.

\section{Law $40 / 2004$ on Rules on Medically Assisted Reproduction}

In Italy there is no law regulating human genome modification per se. ${ }^{45}$ However, there is a law ruling on medically assisted reproduction (Law 40/ 2004), which is relevant for human germline genome editing because it regulates research on "human embryos." The key provision of Law 40/2004 is Article 13, entitled "Experimentations on Human Embryos." It reads:

1. Experimentations on human embryos are prohibited.

2. Clinical and experimental research on human embryos is permitted provided it pursues only therapeutic and diagnostic purposes, aimed at protecting the health and development of the embryo itself, and where alternatives are not available.

3. The following are in any case prohibited: a) the production of human embryos for research or experimentation purposes or in any case for purposes other than the one set by this law; b) any form of eugenic selection of embryos and gametes or interventions that, through selection techniques, manipulation or artificial procedures, aim at altering the genetic heritage of the embryo

43 Oviedo Convention, art. 28.

44 Parliamentary Assembly of the Council of Europe, The Use of New Genetic Technologies in Human Beings (n 36) para 5.

45 However, Article 81 "Quinquies" of the Industrial Property Code - Legislative Decree No. 30 of 10 February 2005 "Codice della proprietà industriale, a norma dell'articolo 15 della legge 12 dicembre 2002, n. 273" (Code of industrial property, in accordance with Article 15 of Law No. 273 of December 12, 2002) states that procedures for modifying the germline genetic identity of the human being are excluded from patentability, and thus, from commercial exploitation. It implements Directive 98/44/EC of the European Parliament and of the Council of July 6, 1998 on the legal protection of biotechnological inventions [1998] OJ L213/13. 
or the gamete, or set genetic features, with the exception of interventions for diagnostic and therapeutic purposes, as per paragraph 2 of this article; c) cloning by nucleus transfer or early embryo splitting or ectogenesis whether for procreative or research purposes; d) the fertilization of a human gamete with a gamete of different species and the production of hybrids or chimeras.

4. The violation of the prohibitions referred to in paragraph 1 shall be punished with imprisonment from two to six years and with a fine ranging from 50.000 to 150.000 euros. In the case of violation of one of the prohibitions referred to in paragraph 3 , the penalty is increased. Mitigating circumstances cannot be considered equivalent or prevalent on the aggravating circumstances envisaged by paragraph 3 .

5. Healthcare professionals who are found guilty of one of the offenses referred to in this article are suspended from exercising their profession for a term between one to three years.

Law 40/2004, approved after an intense debate not only in the Parliament but also within civil society, filled a significant normative gap. ${ }^{46}$ It also opened "a Pandora's box of ethical and technical issues," 47 fueling an already intense debate over challenging and sensitive issues. Rather than providing clear directions for the application of medically assisted reproduction techniques, it just aimed at strictly restraining their use. It posed limits on the number of embryos that could be created at any one time and banned embryo cryopreservation, as well as technologies using a third party and PGD of the embryos. Eventually and unsurprisingly, the Italian Constitutional Court found several of its provisions unconstitutional, ${ }^{48}$ while the ECtHR declared the prohibition of PGD

JA Robertson, "Protecting Embryos and Burdening Women: Assisted Reproduction in Italy" (2004) 19:8 Human Reproduction 1693; A Boggio, "Italy Enacts New Law on Medically Assisted Reproduction" (2005) 20:5 Human Reproduction 1153; I Riezzo and others, "Italian Law on Medically Assisted Reproduction: Do Women's Autonomy and Health Matter?" (2016) 16 BMC Women's Health 44.

47 V Fineschi and others, "The New Italian Law on Assisted Reproduction Technology (Law 4o/ 2004)" (2005) 31 Joumal of Medical Ethics 536, 539.

$4^{8}$ The Constitutional Court, with Judgment No. 151/2009, has declared unconstitutional Art. 14.2 (insofar as it imposed the creation of a limited number of embryos - maximum of three and the duty to implant them simultaneously in utero), and Art. 14.3 (insofar as it did not provide that the transfer of the embryos should be made without prejudice to the health of the woman). With Judgment No.162/2014, the Court has then declared unconstitutional Art. 4.3, Art. 9, sections 1 and 3 (limited to the phrase "in breach of the prohibition laid down by Article 4.3"), and Art. 12.1, insofar as they ruled out recourse to heterologous techniques in the event of medically established sterility or infertility. Finally, Judgments Nos. 96/2015 and 229/2015 (n 31) considered the exclusion of fertile people carriers of transmittable genetic diseases from medically assisted reproduction technology. 
in violation of Article 8 of the European Convention on Human Rights in the case Costa and Pavan v. Italy. ${ }^{49}$

In Judgment 229/2015, the Constitutional Court declared the unconstitutionality of Articles 13.3.b and 13.4 because they criminalized the selection of embryos even when it is aimed at avoiding the implantation of embryos affected by genetic transmissible diseases that meet the severity criteria set forth in Article 6.1.b of the Law 194/1978 regulating abortion. ${ }^{50}$ This decision was consistent with the conclusions reached in its previous Judgment 96/2015 and by the European Court in the case Costa and Pavan.

However, on the question of the ban on research on cryopreserved supernumerary embryos, both the Italian Constitutional Court and the ECtHR have been less trenchant. First, in Parrillo v. Italy, in the light of a lack of European consensus on the matter, the European Court recognized that States have a wide margin of appreciation on this sensitive issue. Thus, it ruled out that such prohibition violates Article 8 of the European Convention..$^{51}$ Then, in Judgment 84/2016 the Constitutional Court rejected as inadmissible a request of a ruling on the constitutionality of the ban, issued by the Tribunal of Florence on December 7, 2012. In the decision, the Constitutional Court affirmed that it is within the powers of the legislator, "acting as the interpreter of the general will, ... to strike a balance through legislation between the fundamental values that are in conflict, taking account of the views and calls for action that it considers to be most deeply rooted at any given moment in time within the social conscience." ${ }^{2}$

After these two decisions, Article 13 of the Law 40/2004 remains an extremely ambiguous provision as far as genome editing is concerned. On the one hand, the Article prohibits experimentations on embryos in general terms (paragraph 1) and explicitly bans interventions that, "through selection techniques, manipulation or artificial procedures, aim at altering the genetic heritage of the embryo or the gamete, or set genetic features" (paragraph 3). On the other hand, it leaves the door open for possible diagnostic or therapeutic application of gene editing (paragraphs 2 and 3 ).

49 Costa and Pavan v. Italy (n 30$)$.

50 Law No. 194/1978 "Rules for the social protection of motherhood and voluntary termination of pregnancy" (Norme per la tutela sociale della maternità e sull'interruzione volontaria della gravidanza).

51 European Court of Human Rights, Parrillo v. Italy (2015) application no. 46470/11, para 174-176.

52 Constitutional Court Judgment No. 84/2016, para 11. 


\section{The Opinion on Ethical Considerations Surrounding Gene Editing and CRISPR-CAS9 Technique of the National Committee for Bioethics}

The overview of the Italian regulatory framework would not be complete without mentioning the Opinion on Ethical Considerations Surrounding Gene Editing and CRISPR-CAS9 Technique, released by the Italian Committee for Bioethics (Comitato Nazionale per la Bioetica - ICB) on February 23, 2017 ("2017 Opinion").53 The ICB was established in 1990 by the Council of Ministers, with the task of advising the Presidency of the Council of Ministers, and even drafting laws, on ethical and legal problems arising out of advances in biological scientific research and technological applications. ${ }^{54}$ While ICB documents are not per se binding, they contribute to stimulate and drive political and legal debate over ethically controversial issues.

In its 2017 Opinion, the Committee expresses its favor for animal experimentation (as long as it is performed according to international rules) with the aim to test the safety and effectiveness of gene editing on germline and embryos. ${ }^{55}$ While encouraging research on gene editing on human somatic cells, ${ }^{56}$ the Committee unanimously rejects experimentation on gametes that are intended to be used in reproduction and on human embryos to be implanted. ${ }^{57}$

With regard to gene editing on gametes that are not to be used in reproduction and/or on embryos that are not to be implanted, the Committee's members are split. One view is that the moratorium on clinical research should not be extended to in vitro basic research on these gametes and embryos because this would mean "precluding research aiming at improving [gene editing]" and because the findings of this research are necessary to assess the scientific feasibility and ethical acceptability of clinical applications in the future..$^{8}$ The other view is that basic research is not currently justified, considering that, from a clinical perspective, gamete selection is preferable to gamete editing and that assessing the effectiveness and safety of in vitro gene

53 Italian Committee for Bioethics (ICB), "L'editing genetico e la tecnica CRISPR-CASg: considerazioni etiche" (February 23, 2017). http://bioetica.governo.it/it/documenti/pareri-e-ris poste/l-editing-genetico-e-la-tecnica-crispr-cas9-considerazioni-etiche accessed July 31, 2018.

Ibid. para. 4.2.

57 Ibid. para. 5 .

$5^{8}$ Ibid. para. 5.1. This is the position of nine members of the Committee (Professors Battaglia, Canestrari, Casonato, de Curtis, Di Segni, Flamigni, Garattini, Toraldo di Francia, Zuffa). 
editing on embryos is not possible, since results of the genetic modification can be assessed only at birth or even later. ${ }^{59}$

\section{Oversight Bodies for Research on Human Germline Modification}

In Italy, a number of bodies oversee biomedical research. Governmental bodies include the Ministry of Health (Ministero della Salute) and the Ministry of University and Scientific Research (Ministero dell'Universitá e della Ricerca Scientifica).

Additionally, a number of independent bodies (Comitati Etici) have been established in universities, in public health facilities and in the so-called healthcare research institutes (Istituti di ricovero e cura a carattere scientifico), where clinical research activities are carried out. While the organizational set up of Committees varies from region to region, all Committees are called to evaluate and approve clinical trial protocols. In addition, their powers extend to issues concerning the use of medicinal products and medical devices as well as of surgical and clinical procedures. ${ }^{60}$ In more detail, according to Article 1 of Ministry of Health Decree of February 8, 2013, the Ethics Committees

1. [...] have the responsibility to ensure the protection of the rights, safety and well-being of people taking part to experimentations and to provide public guarantees of such protection.

2. Where not already assigned to specific bodies, ethics committees can also perform advisory functions in relation to ethical issues related to scientific and welfare activities, in order to protect and promote fundamental values. The ethics committees, moreover, can propose training initiatives for health personnel regarding issues related to bioethics. ${ }^{61}$

The general framework of Ethics Committees has been modified in time. The most recent reform took place in 2018 when Law $3 / 2018^{62}$ reduced the

59 Ibid. para. 5.2. This is the position of nine members of the Committee (Professors Amato, Caltagirone, Dallapiccola, D’Agostino, Gensabella, Morresi, Palazzani, Proietti, Scaraffia).

6o Law No. $189 / 2012$ "Conversion into law, with amendments, of the law decree n. 158 of 13 September 2012, containing urgent provisions to promote the development of the country through a higher level of health protection" (Conversione in legge, con modificazioni, del decreto-legge 13 settembre 2012, n. 158, recante disposizioni urgenti per promuovere lo sviluppo del Paese mediante un più alto livello di tutela della salute), art 12.10.c.

61 Ministry of Health Decree of February 8, 2013, "Criteria for the composition and functioning of ethics committees" (Criteri per la composizione e il funzionamento dei comitati etici).

62 Law No. 3/2018, "Delegation to the Government in the matter of clinical trials of medicines, containing provisions for the reorganization of the health professions and for the health leadership of the Ministry of Health" (Delega al Governo in materia di sperimentazione clinica 
number of the Committees to a maximum of 40 throughout the country and established the "National Coordinating Center for Territorial Ethics Committees" (Centro di coordinamento nazionale dei comitati etici territoriali), with the mission to coordinate, guide, and monitor the activities of all Ethics Committees. In exceptional cases, the National Coordination Center might be involved in the evaluation of studies requiring a review for security reasons.

Finally, as already mentioned, the Italian Committee for Bioethics might provide opinions on ethical and legal problems arising out of advances in biological scientific research and technological applications.

Still, despite the existence of numerous entities with oversight competences, there are no governmental or nongovernmental bodies explicitly tasked to monitor research involving human genome editing per se.

\section{Funding Opportunities}

At this point in history, research on human germline genome modification cannot be funded with public money. It cannot be funded with EU money either. EU Regulation No. 1291/2013, ${ }^{63}$ establishing "Horizon 2020," the Framework Programme for Research and Innovation (2014-2020), explicitly excludes from funding research activities intended to modify the genetic heritage of human beings that could make such changes heritable. ${ }^{64}$ While the European Union left the door open for a possible review of this exclusion "in the light of scientific advances," to date no exceptions have been made. ${ }^{65}$

Whether research on human germline genome modification is privately funded and carried out in Italy is unknown, but it is unlikely because researchers and funders would be under threat of criminal prosecution under paragraphs 4 and 5 of Article 13 of Law $40 / 2004$.

di medicinali nonché disposizioni per il riordino delle professioni sanitarie e per la dirigenza sanitaria del Ministero della salute).

63 EU Regulation No. 1291/2013 of the European Parliament and of the Council of December 11, 2013 establishing Horizon 2020 - the Framework Programme for Research and Innovation (2014-2020) and repealing Decision No. 1982/2006/EC (2013) OJ L 347/104.

64 With the sole exception of research relating to cancer treatment of the gonads: EU Regulation No. $1291 / 2013$, art. 19 .

65 Communication from the Commission to the European Parliament, the Council, the European Economic and Social Committee and the Committee of the regions, "Horizon 2020 interim evaluation: maximizing the impact of EU research and innovation", COM (2018) 2 final, (January 11, 2018). 


\section{SUBSTANTIVE PROVISIONS}

Having presented the regulatory environment in general terms, it is now possible to determine if, and to what extent, research using germline modification is permitted in the Italian legal system at each step of the research cycle.

\section{Basic Research}

\section{a Genome Modification in Human Embryos}

As we saw, Article 13 of Law 40/2004 provides:

1. Experimentations on human embryos are prohibited.

2. Clinical and experimental research on human embryos is permitted provided it pursues only therapeutic and diagnostic purposes, aimed at protecting the health and development of the embryo itself, and where alternatives are not available.

Although Article 13 of Law 40/2004 is a very ambiguous norm, at least it is clear it does not allow human germline genome modification basic research on embryos (paragraph 1). By "basic research," we mean research done in laboratory, in vitro, aimed at improving scientific knowledge and "performed without thought of practical ends." ${ }^{66}$ Considering that Law 40/2004 does not provide a definition of "embryo," the ban of experimentation contained in Article 13 possibly includes also zygotes (pre-embryos), which, since $2009,{ }^{67}$ can be frozen as part of in vitro fertilization, whenever the physician believes that the transfer in utero is not compatible with the health conditions of the woman. $^{68}$

Article 13.3 explicitly prohibits the production of human embryos for research or experimentation purposes (as well as human cloning and the creation of hybrids or chimeras). Moreover, Article 14 prohibits the removal of embryos. ${ }^{69}$ Thus, not only supernumerary healthy

66 V Bush, Science: The Endless Frontier (United States Government Printing Office, 1945), c 3. See also N Roll-Hansen, "Why the Distinction between Basic (Theoretical) and Applied (Practical) Research is Important in the Politics of Science" (2009) Centre for the Philosophy of Natural and Social Science Contingency and Dissent in Science Technical Report o4/o9, 4 https://pdfs.semanticscholar.org/62fo/dced123c24c7bc89b7dod72bfcf885634a43.pdf accessed February 27, 2017).

${ }^{6}$ Due to the exception - de facto introduced by Constitutional Court Judgment No. 151/2009to the prohibition of cryopreservation of embryos (n 48).

68 Private communication, Dr. Gianluca Gennarelli, Senior Consultant, responsible person for medically assisted fertilization procedures at Ospedale Sant'Anna, Turin.

69 Law 40/2004, art. 14 . 
embryos $^{70}$ but even embryos affected by a genetic disorder (which, for this reason, will not be transferred in utero) are kept in cryopreservation sine die, since they cannot be destroyed nor used for research. Italian scientists cannot create embryonic stem cell lines because doing so requires the destruction of at least one embryo. However, they are not prohibited from working on imported lines, and they do so.

Such a legal framework not only generates unnecessary hindrances for scientists who operate in Italy, but it might be also considered as a violation of Article 15 of ICESCR. In 2017, a communication was submitted to the Committee on Economic Social and Cultural Rights, raising the question of the compatibility of the Italian legislation with the right to science guaranteed under the Covenant. In particular, as far as Article 15 is concerned, Law 40/2004 has been challenged by a couple of healthy carriers of a serious hereditary disease who could not donate to science their embryos affected by such a disorder. The applicants argued that, by prohibiting research on embryos, even those affected by genetic disorders, Law 4o/ 2004 interferes with scientific progress, slowing down the search for a cure for various diseases; secondly and consequently, in doing so, Law 40/2004 violates their right to enjoy the benefits of scientific progress and its applications and prevents them from participating in scientific research by donating their embryos affected by a genetic disorder. The Commitee, however, has declared inadmissible the communication in relation to this issue, considering that the authors (who have not claimed the intention to perform themselves any scientific research) cannot be considered victims of a violation of their freedom of research. ${ }^{11}$

\section{b Germline Modification in Human Gametes}

As far as gametes are concerned, some issues are clearly regulated, while others remain ambiguous. The prohibition contained in Article 13.3 of Law 40/2004 refers only to the production of embryos for research. Thus, the production of "artificial" gametes (i.e., gametes derived from pluripotent cells via in vitro gametogenesis) is permitted in Italy. Basic research on "artificial" and

70 According to the 2015 guidelines on medically assisted procreation, all embryos which are not immediately transferred in utero have to be frozen and cryopreserved at the centers where the techniques were carried out and the related charges are borne by the same centers: Ministry of Health Decree of 1 July 2015, "Guidelines containing indications for medically assisted procreation procedures and techniques" (Linee guida contenenti le indicazioni delle procedure e delle tecniche di procreazione medicalmente assistita), 117.

${ }^{71}$ Committee on Economic, Social and Cultural Rights, CSA and GP v. Italy, Communication No. 22/2017, Views adopted by the Committee under the Optional Protocol of the Covenant, 7 March 2019, UN Doc. E/C.12/65/D/22/2017, para 6.19. 
"natural" gametes is also permitted, considering that it is not banned in clear words unlike the prohibition of experimentations on embryos.

As far as gametes procurement is concerned, the Ministry of Health is working on a regulation to transpose the relevant EU directives, ${ }^{72}$ specifying quality and safety standards for donated human tissues and cells, in the Italian legal system. The guidelines adopted by the Ministry of Health in 2015, which are rather directed to couples accessing ART (assisted reproduction technologies) treatments, are silent as to gametes donors. In case of heterologous fertilization, they prohibit intended parents from choosing particular phenotypic characteristics of the donor to avoid illegitimate eugenic selection. ${ }^{73}$

As it will be recalled, Article 13.3.b of Law 40/2004 prohibits

any form of eugenic selection of embryos and gametes or interventions that, through selection techniques, manipulation or artificial procedures, aim at altering the genetic heritage of the embryo or the gamete, or set genetic features, with the exception of interventions for diagnostic and therapeutic purposes, as per paragraph 2 of this article.

A key interpretative doubt emerges from the reading of this norm and concerns the definition of "intervention." If "intervention" refers exclusively to clinical activity (i.e., in vivo, on patients), the prohibition of manipulation does not apply to in vitro research on gametes, and their manipulation is allowed. This interpretation would be consistent with the way the word "intervention" is used elsewhere in Law 40/2004, where it is used in the context of medically assisted reproduction procedures and not research as such. ${ }^{74}$ It would be also consistent with the other prohibition listed in the provision, namely the "selection for eugenic purposes." It is clear, indeed, that this kind of selection can be realized only in a clinical activity (i.e., in a medically assisted reproduction procedure), since the eugenic purpose per se implies the transfer in utero as it is connected with the potential birth of a new individual.

72 Directive 2004/23/EC of the European Parliament and of the Council of March 31, 2004 on setting standards of quality and safety for the donation, procurement, testing, processing, preservation, storage and distribution of human tissues and cells (2004) OJ L 102/48; Commission Directive 2006/17/EC of February 8, 2006 implementing Directive 2004/23/EC of the European Parliament and of the Council as regards certain technical requirements for the donation, procurement, and testing of human tissues and cells (2006) OJ L 38/40; Commission Directive 2006/86/EC of October 24, 2006 implementing Directive 2004/23/EC of the European Parliament and of the Council as regards traceability requirements, notification of serious adverse reactions and events, and certain technical requirements for the coding, processing, preservation, storage, and distribution of human tissues and cells (2006) OJ L294/32.

73 Ministry of Health Decree of July 1, 2015, 113.

74 See arts 2, 4, 10, 15, 16. 
However, Article 13 deals with research and not with clinical activity. For this reason the term "intervention" might need to be given a special meaning, different from the one given to it in other sections regulating other stages of research. If that is the case, the legitimacy of gametes manipulation depends on whether or not they are manipulated for therapeutic or diagnostic purposes: Only manipulation pursuing such aims would be allowed.

Another relevant issue is whether and to what extent mitochondrial manipulation techniques (MMT) ${ }^{75}$ are permitted under Law 40/2004, considering that "the transfer of female embryos created via MMT can impact future generations through the maternal transmission of mtDNA."76 Preclinical research using MMT seems to be permitted as long as it concerns oocytes not destined to be implanted once fertilized. In addition, clinical applications should also be considered compatible with Article 13, if they aim at protecting the health and development of the embryo itself. This point is of foremost importance, since in the near future MMT might be used "to prevent the onset of serious mitochondrial diseases in offspring as a reproductive option for prospective parents who wish to have a genetically related child and who have experienced PGD failure due to the high load of mtDNA mutations in the oocytes." 77

\section{Preclinical Research Using Germline Genome Modification Technologies}

The Legislative Decree No. 26, of March 4, 2014, ${ }^{78}$ implementing Directive 2010/63/EU on the Protection of Animals Used for Scientific Purposes, implicitly allows germline genome modification research on animals. ${ }^{79}$ In particular, this conclusion can be derived from the definition of "procedure" detailed under Article 3.1.a of the Legislative Decree, as

any use, invasive or non-invasive, of an animal for experimental or other scientific purposes, with known or unknown outcome, or educational

75 "Thus, MMT can alter the mtDNA content of human oocytes or zygotes through CT, karyoplast transfer (which includes carryover mtDNA) or autologous mitochondrial transfer (which might undergo mutagenesis during preparation) to treat intractable infertility or prevent mitochondrial disease in offspring": T Ishii and Y Hibino, "Mitochondrial Manipulation in Fertility Clinics: Regulation and Responsibility" (2018) 5 Reproductive BioMedicine and Society Online 93, 94 https://doi.org/10.1016/j.rbms.2018.01.002 accessed July 31, 2018.

$7^{6}$ Ibid. 95 .

77 Ibid. 107 .

$7^{8}$ Legislative Decree No. 26/2014, "Implementation of Directive 2010/63/EU on the protection of animals used for scientific purposes" (Attuazione della direttiva 2010/63/UE sulla protezione degli animali utilizzati a fini scientifici).

79 Directive 2010/63/EU of the European Parliament and of the Council of September 22, 2010 on the protection of animals used for scientific purposes (2010) OJ L276/33. 
purposes, which may cause the animal a level of pain, suffering, distress or lasting harm equivalent to, or higher than, that caused by the introduction of a needle in accordance with good veterinary practice. This includes any action that intends or may lead to a series of genetically modified animals with a phenotype suffering in these conditions. ${ }^{80}$

As in any research on animals, limits and conditions are imposed to germline modification technologies. In particular, animals can be only used for scientific purposes when no other experimental method or strategy not involving the use of living animals and that is scientifically valid and reasonably and practically applicable is available. ${ }^{81}$ Additionally, in Italy, raising genetically modified animals is allowed under the authorization of the Ministry of Health, provided the risks and benefits, the extent to which the manipulation is needed, the possible impact on the welfare of the animals, and the potential risk for human health, animal health, and the environment are assessed in advance. ${ }^{82}$ Moreover, specific provisions apply to research on endangered species (Article 7), nonhuman primates (Article 8), animals taken from the wild (Article 9), stray and feral animals of domestic species, including dogs and cats (Article 11).

\section{Clinical Research Using Germline Genome Modification Technologies}

Clinical research using human germline genome modification is explicitly prohibited by Legislative Decree No. 211 of June 24, 2003, ${ }^{83}$ implementing Directive $2001 / 20 / \mathrm{EC}$ on good clinical practice in the conduct of clinical trials on medicinal products for clinical use. ${ }^{84}$ Article 9.6 of the Legislative Decree requires the "sponsor" 85 to obtain written authorization by the Ministry of

8o Also, Art. 17.1 states that " [a] procedure is considered terminated (...) when, in the case of new lines of genetically modified animals, transmission of genetic alteration has not given rise to or is not expected to give rise, with regard to descendants, to a level of pain, suffering, distress or prolonged injury equivalent or superior to that caused by the insertion of a needle."

81 Legislative Decree No. 26/ 2014, art 1.2.

82 Ibid., art. 10.4.

83 Legislative Decree No. 211/2003, "Implementation of Directive 2001/20/EC on the application of good clinical practice in the execution of clinical trials of medicinal products for clinical use" (Attuazione della direttiva 2001/20/CE relativa all'applicazione della buona pratica clinica nell'esecuzione delle sperimentazioni cliniche di medicinali per uso clinico).

84 Directive 2001/20/EC of the European Parliament and of the Council of 4 April 2001 on the approximation of the laws, regulations, and administrative provisions of the Member States relating to the implementation of good clinical practice in the conduct of clinical trials on medicinal products for human use (2001) OJ L121/34.

85 Namely, "an individual, company, institution or organization which takes responsibility for the initiation, management and/or financing of a clinical trial": Legislative Decree No. 211/ 2003 , art 2.3.e. 
Health before the beginning of clinical trials involving the use of gene therapy but affirms that "trials of gene therapy that lead to changes in the germline genetic properties of the subject cannot be performed." 86 The provision replicates almost verbatim Article 9.6 of the Directive 2001/20/EC, which requires authorization by the competent authority in Member States "before commencing clinical trials involving medicinal products for gene therapy, somatic cell therapy including xenogenic cell therapy and all medicinal products containing genetically modified organisms" and prohibits any gene therapy trials "which result in modifications to the subject's germ line genetic identity." 87

In 2014, the Directive was repealed by EU Regulation 536/2014. ${ }^{88}$ However, implementation of EU Regulation 536/2014 depends on the development of a fully functional EU clinical trials portal and database, which is estimated to occur in 2020. Echoing the Directive, Article 90 of the Regulation, entitled "Specific requirements for special groups of medicinal products," provides that "no gene therapy clinical trials may be carried out which result in modifications to the subject's germ line genetic identity."

\section{Clinical Applications of Germline Genome Modification Technologies}

Counterintuitively, Article 13 of Law 40/2004 leaves the door open to clinical applications of germline modification technologies. As it has been recalled, Article 13 allows clinical and experimental research on human embryos, including "selection techniques, manipulation or artificial procedures, aim[ing] at altering the genetic heritage of the embryo or the gamete, or set genetic features," tic purposes, aimed at protecting the health and development of the embryo itself, and where alternatives are not available." ${ }^{\circ}$

Although extremely ambiguous, this part of Article 13 ought to be interpreted as dealing with clinical applications and not with clinical research as such. We intend clinical application as referring to approved therapies that cure embryos from genetic defects and ensure their development. These therapies would be consistent with the "therapeutic purposes," on which the

86 Ibid., art. 9.6.

87 Directive 2001/20/EC, art. 9.6.

88 EU Regulation No. 536/2014 of the European Parliament and of the Council of April 16, 2014 on clinical trials on medicinal products for human use, and repealing Directive 2001/20/EC (2014) OJ L 158/1.

89 Law $40 / 2004$, art. 13.3.b.

90 Ibid., art. 13.2 . 
provision insists. On the contrary, clinical research remains prohibited, also considering that, due to the principle of primacy of EU law over domestic sources referred to above, Article 13 of Law 40/2004 must be interpreted consistently with the mentioned EU norms (in particular, EU Regulation 536/2014), prohibiting gene therapy trials resulting in modifications to the subject's germline.

As such, clinical applications of germline modification technologies are not prohibited by Law $40 / 2004$.

\section{CURRENT PERSPECTIVES AND FUTURE POSSIBILITIES}

For historical, social, and religious reasons, Italy has always been very conservative when it comes to life sciences. This exceedingly cautious attitude is reflected in Law 40/2004, at least in its original version before being chipped away by the Constitutional Court and ECtHR. Thus, it seems bizarre that Law 40/2004 prohibits basic research and clinical trials of human germline genome modification but does not prohibit its clinical application. It is probably an accidental paradox, the result of badly and hastily drafted legislation. However, it might be a serendipitous omission, one that is consistent with the overall aim of Law 40/2004: to protect the embryo. Curing it from genetic diseases would further this goal.

However, given the prevailing attitude among Italian lawmakers, particularly in the field of life sciences, there are still many doubts about the concrete possibility that the Ministry of Health might give the green light to clinical applications that lead to a modification of the human germline genome. It is also impossible, at present, to define whether these techniques can be considered as medicines - and, therefore, follow the process that, through the role of Ethical Committees referred to above, terminates with the authorization granted by the Italian Agency for Drugs (Agenzia Italiana del Farmaco) - or whether they should be classified differently.

In any event, recent developments and new possibilities in the field of human germline genome modification call for regulations that, while setting limits to contain possible abuses, do not wholly frustrate scientific and technological progress..$^{91}$ As it has been correctly stated, we are witnessing "a complex - more implicit than explicit - negotiation process between

91 EM Kane, "Human Genome Editing: An Evolving Regulatory Climate” (2017) 57 Jurimetrics J. 301 . 
science and society taking place regarding which technique should be developed and used and for which reason this should or could be done."92

As far as Italy is concerned, considering that the ban on clinical research using germline modification technologies comes from EU law, the only space for a normative change concerns basic research applying human germline genome modification on embryos. This is currently outlawed by Law 40/2004, but it should be permitted, under certain conditions (such as the informed consent of people whose gametes have been used). Only the improvement of basic research on gametes would in fact permit future decisions on whether, and possible identification of which, clinical applications are scientifically feasible and ethically acceptable. ${ }^{93}$ Italy's prohibition of research on cryopreserved supernumerary embryos, which, in any case, are not meant to be implanted and are therefore destined to remain stored sine die, unreasonably hampers two fundamental rights: the right to science and the right to health.

The approach toward the regulation of human germline genome editing should also be reconsidered at the international level. So far, concerns for potential misuses and abuses of human germline genome modification have determined an extremely cautious attitude toward these technologies, as illustrated, among other documents, by the Report on Pre-implantation Genetic Diagnosis and Germline Intervention prepared by the International Bioethics Committee of UNESCO. ${ }^{94}$ However, it is paramount to develop greater awareness of the potential of these scientific innovations and, while maintaining a high level of attention for possible dangerous drifts, to limit the constraints to research in this field, with the aim to promote a full realization of the right to science.

92 M Braun and P Dabrock, "II bet you won't': The Science-society Wager on Gene Editing Techniques" (2016) 17:3 EMBO reports 279. According to the authors, "[t] he current debate on gene editing could perhaps be understood as a wager between science and society: one side mostly scientists - is trying to guess and cater for the possible reaction of the other side, while the other side - mostly the public - is trying to discern the underlying intentions and goals of the other."

93 D Baltimore and others, "A Prudent Path Forward for Genomic Engineering and Germline Gene Modification" (2015) 348:6230 Science 36; Italian Committee for Bioethics (ICB), L'editing genetico (n 53 ) 15.

94 UNESCO - International Bioethics Committee, "Report of the IBC on Pre-implantation Genetic Diagnosis and Germ-line Intervention" (2003) SHS-EST/o2/CIB-9/2(Rev.3). 